\title{
Correction to: Evaluation of chemical compositions and antioxidant potential of marine microalgae of the genus Nannochloropsis
}

\author{
D. Thinesh Santhar ${ }^{1,2} \cdot$ M. A. Badhul Haq ${ }^{2}$ Thangapandi Marudhupandi ${ }^{3} \cdot$ Baskaralingam Vaseeharan $^{3}$. \\ Durairaj Karthick Rajan ${ }^{3}$ Meivelu Moovendhan ${ }^{4}$
}

(c) Springer-Verlag GmbH Germany, part of Springer Nature 2021

\section{Correction to: Biomass Conversion and Biorefinery https://doi.org/10.1007/s13399-021-01929-5}

In this article the affiliation details for Baskaralingam Vaseeharan was wrongly mentioned as 4 instead of 3 .

The original article has been corrected.

Publisher's note Springer Nature remains neutral with regard to jurisdictional claims in published maps and institutional affiliations.

The original article can be found online at https://doi.org/10.1007/ s13399-021-01929-5.

\section{Thangapandi Marudhupandi}

tmarudhu@gmail.com

1 Rajiv Gandhi Centre for Aquaculture, Marine Products Export Development Authority, Ministry of Commerce \& Industry, Govt of India, Kodiyaghat, Burmanalla PO, Garacharma (Via), South Andaman 744 105, Andaman \& Nicobar Islands, India

2 Centre of Advanced Study in Marine Biology, Faculty of Marine Sciences, Annamalai University, Parangipettai 608502, India

3 Department of Animal Health and Management, Alagappa University, Karaikudi 630003, Tamil Nadu, India

4 Bio-Engineering and Drug Design Laboratory, Department of Biotechnology, Bhupat \& Jyoti Mehta School of Biosciences, Indian Institute of Technology, Madras (IIT-M), Chennai 600036, Tamil Nadu, India 